\title{
Chileans, climate change and the natural environment: An audience segmentation study
}

Chilenos, cambio climático y medio ambiente: un estudio de segmentación de audiencia

Rodolfo Jorge Patricio Sapiains Arrué (iD http://orcid.org/0000-0003-0366-5553

Universidadde Chile, Chile, rodolfo.sapiains@gmail.com Gabriela Alejandra Azócar de la Cruz (D) https://orcid.org/0000-0002-8282-1122 Universidad Alberto Hurtado, Chile, gabriela.azocar@gmail.com Ana María Ugarte Caviedes* (D) http://orcid.org/0000-0003-0699-3085

Universidad deChile, Chile, amuc@u.uchile.cl

Javier Alberto Romero Hernández (iD http://orcid.org/0000-0003-2129-0628

Universidad de Chile, Chile, javier.romero.h@ug.uchile.cl

${ }^{*}$ Corresponding author:

Ana María Ugarte

Caviedes,

amuc@u.uchile.cl

Reception: 16/12/2020

Approval: 23/04/2021

Publicación: 15/06/21

Abstract: Not much research has been carried out in Latin America on the human dimensions of climate change. An audience segmentation study was conducted in Chile to explore different perspectives about this issue, using data from a national survey $(n=2170)$. Results showed most Chileans express high levels of concern and agree climate change is happening and caused mainly by human actions. On the contrary, differences were found on worldviews, behaviors, perceptions of control among other factors, allowing the identification of three groups: Pragmatics, Neoliberals and Environmentalists. These results can contribute to the design of more effective communication strategies to increase awareness and climate action.

Key words: audience segmentation, climate change communication, Chile, climate change beliefs, environmental worldviews.

Resumen: Hasta la fecha, en América Latina, las investigaciones sobre las dimensiones humanas del cambio climático son aún escasas. Para aportar a este campo, se realizó un estudio de segmentación de audiencia en Chile, que buscó explorar distintas perspectivas sobre este tema, utilizando datos de una Encuesta Nacional $(\mathrm{n}=2170)$. Los resultados mostraron que la mayoría de los chilenos expresan altos niveles de preocupación y están de acuerdo en que el cambio climático está sucediendo y es causado principalmente por acciones humanas. Por otro lado, se encontraron diferencias en cosmovisiones, comportamientos, y percepciones de control, entre otros factores, permitiendo la identificación de tres grupos: pragmáticos, neoliberales y ambientalistas. Estos resultados pueden contribuir a diseñar estrategias de comunicación más efectivas para aumentar la concienciación y la acción climática.

Palabras clave: segmentación de audiencias, comunicación del cambio climático, creencias sobre el cambio climático, cosmovisiones ambientales. 


\section{Introduction $^{1}$}

Chile is one of the most vulnerable countries to climate change impacts, presenting seven out of nine vulnerability criteria (Oficina de Cambio Climático, 2014). Although the national contribution to global greenhouse gas emissions is quite low, around $0.22 \%$ of the total, the level per capita ( 6 tons per year) is one of the highest in Latin America, even higher than Brazil and Mexico (Global Carbon Proyect, 2018; Burck et al., 2019; World Bank, 2020). During the last two decades, the country has developed multiple initiatives, including national and sectorial adaptation plans, creating a climate change department, subscribing to international agreements (e.g., Kyoto and Paris), increasing investment in solar energy, and financing important academic projects. Moreover, there is an ongoing discussion on a climate change bill that should be enacted in 2021. However, while research on climate changes from a natural-science perspective is strong and growing steadily, and policy initiatives at the government level are observed, studies on the human dimensions to explain how people here perceive and more importantly respond to climate change are still scarce.

Indeed, it is clear that despite scientific consensus on the importance of climate change and the role human activities play in causing it (Cook et al., 2013; Cook et al., 2016), perceptions about the problem vary worldwide. Many studies (Pasek, 2018; Bain et al., 2012; Newman et al., 2018; Corner et al., 2012; Kahan et al., 2012; Bertoldo et al., 2019) show that what people think about controversial problems such as climate change is more strongly associated with previous beliefs and values than with an accurate and rational understanding of the science behind a particular issue.

Here in Chile, a national survey $(\mathrm{n}=2170)$ on climate change beliefs, attitudes and behaviors was conducted in 2016 as part of a study aimed at exploring how Chileans perceive and respond to different aspects of this issue (Sapiains et al., 2017). Results showed that $84 \%$ of Chileans think climate change is happening or will happen at some point in the future, and among those, $89 \%$ thinks it is caused totally or partially by human activities; similarly, Chileans believe climate change impacts will be severe or very severe $(89.8 \%)$, and the country is not well prepared to deal with the problem (95\%).

1 This research was funded by ANID/PAI 2014, grant number: 82140012; Center for Climate and Resilience Research (CR)2, grant number ANID/FONDAP 15110009; ANID/FONDECYT 11190483; and Academic Productivity Support Program PROA VID 2018, Universidad de Chile, PROA027/18. We are incredibly grateful to Diane Greenstein for helping us to review the translation of this document into English. 
Rodolfo Jorge Patricio Sapiains Arrué, Gabriela Alejandra Azócar de la Cruz, Ana María Ugarte Caviedes y Javier Alberto Romero Hernández. Chileans, climate change and the natural environment: An audience segmentation study

These results suggest that Chilean society is not divided or polarized on climate change. Indeed, the proportion of people denying climate change or questioning the importance of anthropogenic factors causing the problem is quite low, mirroring what has been reported in international surveys (Newman et al., 2020), and showing an important difference with the situation in other countries such as the US or Australia (Marlon et al., 2019; McCright et al., 2015; Whitmarsh, 2011). However, the survey also showed aspects of climate change where Chileans do differ, including climate change-related behaviors and environmental worldviews, among others. Thus, in terms of public opinion, the main challenge for our country is to get more people engaged in both implementing better adaptation responses and supporting more ambitious climate policies.

In such a context, audience segmentation studies can help to design more effective and targeted communication strategies to increase awareness and climate action. According to Maibach et al. (2011), audience segmentation is the process of dividing a particular population in homogeneous sub-groups based on psychological and behavioral attributes. The identification of such groups can help to tailor messages to different audiences, build upon the various interests, needs and behavioral patterns of each group, and increase people's engagement with climate change action.

Using the survey database from 2016, we conducted an audience segmentation study aimed at identifying the groups that coexist in Chilean society regarding climate change. To our knowledge, no similar studies have been conducted in Chile nor in Latin America. For this reason, we decided to develop a two-part exploratory study instead of testing previous audience segmentation models.

First, we conducted an analysis to build a typology with the following research question: What segments can be identified in the Chilean population considering climate change beliefs, attitudes and behaviors? Secondly, we explored the interactions between the groups identified and five dimensions of climate change that were included in the database. This is summarized in the following research questions: Do the socio-demographic characteristics of the segments vary among them? Do perceptions of the causes of climate change vary among the segments? Are there significant differences regarding consumer-buying behaviors among the groups? Do the perceptions of climate change impacts vary among the segments? Are there different emotional responses to climate change among the groups? Finally, given the information collected and the audience segmentation study, we suggest differentiated communication strategies that would appeal to each group based on their beliefs, attitudes, behaviors and perceptions. 


\section{Audience segmentation}

In the US, the Six Americas study (Leiserowitz et al., 2015) is aimed at predicting climate change policy support among people from different geographical areas and ideological positions. Using a sample of 2,164 people, researchers identified six segments within American society regarding climate change: Alarmed, Concerned, Cautious, Disengaged, Doubtful and Dismissive. Alarmed were the most worried, the most personally involved, and the most motivated to take action. Those concerned believed that climate change is a serious issue and something must be done about it, though they are less personally involved than the Alarmed. The cautious are only somewhat likely to say that climate change is occurring, but are not likely to take action either as consumers or as citizens on this issue. Those disengaged do not know whether climate change is occurring and whether it will harm people, and do not feel well educated on the topic. The doubtful are unsure whether climate change is occurring and are unlikely to change their minds, though are particularly supportive of policies regarding domestic energy sources. Finally, the Dismissive believe global warming does not exist and are actively working against policies to reduce greenhouse gas emissions.

Hine et al. (2013) conducted a similar study in Australia $(n=3,096)$ to identify the main interpretations of climate change focusing on the human dimensions of adaptation and using an approach that disaggregated cognitive-affective and behavioral dimensions in the profiling process. Five groups were identified: Alarmed, Concerned, Uncertain, Doubtful and Dismissive. These segments vary regarding their climate change behavioral responses, their information consumption on the topic, and their energy policy preferences. Alarmed and Worried showed the most willingness to implement pro-environmental behaviors and to support mitigation and adaptation policies.

Continuing along the same lines, Sherley et al. (2014) grouped Australians $(n=1,927)$ on the six sub-segments identified in the US regarding climate change and found variations regarding climate change attitudes and the willingness to implement pro-environmental behaviors. The cautious think climate change is happening, but only a half thinks human activities are the cause; they also think climate change can be stopped through individual actions. The disengaged generally do not believe climate change is occurring and are not keen on implementing pro-environmental behaviors. 
Rodolfo Jorge Patricio Sapiains Arrué, Gabriela Alejandra Azócar de la Cruz, Ana María Ugarte Caviedes y Javier Alberto Romero Hernández. Chileans, climate change and the natural environment: An audience segmentation study

In Germany, a study $(\mathrm{n}=3000)$ exploring attitudes toward climate change and identifying segments within German society was conducted by Metag (2015) following the Six Americas study. Five of those six segments were identified: Alarmed, Concerned Activists, Cautious, Disengaged, and Doubtful. Overall, the skepticism level in Germany is much lower than in the US, which shows a higher consensus on the importance of the problem and support for related policies.

In Singapore, Detenber et al. (2016) conducted a study $(\mathrm{n}=1006)$ to explore how different groups within the population perceive and respond to climate change. Three segments were identified. Concerned, including those who express the greatest worry about climate change, hold the strongest beliefs that global warming will harm them personally and have engaged in a fair amount of pro-environmental actions. Disengaged, they are slightly older than the Concerned segment and have below average education and income, and were generally found to have inaccurate beliefs regarding global warming despite scientific consensus; they are not worried about climate change in general nor do they believe it will harm them personally, they are the least likely to believe that global warming should be a high government priority. And, passive, including the oldest, least educated and with the lowest incomes. They believe in climate change, but express a moderate worry about it and hold a moderate belief that it will harm them. These results contrast with the studies in the US, Australia and Germany, highlighting the importance of considering cultural differences in climate change communication.

Finally, Poortinga and Darnton (2016) conducted a study $(n=1,538)$ in Wales to identify different segments in the population with a focus on sustainability considering social, economic and environmental factors, associated with pro-environmental actions. Six segments were identified. Enthusiasts, who had positive views on all aspects of sustainability and sustainable living, and were also the segment most concerned about climate change. Pragmatists, who were relatively concerned about climate change and expressed positive views on sustainable living; however, they only engaged moderately in environmental sustainability and energy security issues. Aspirers, who expressed one of the lowest levels of concern regarding energy security and reported low levels of social capital and place attachment. Those community-focused were conservative and engaged with their Community. Although they endorsed both environmental and economic sustainability, they thought that economic growth and jobs should take priority over the environment. Commentators were the least engaged with environmental 
sustainability and most likely to prioritize the economy over the environment. Finally, the Self-Reliant had negative views on environmental sustainability, sustainable living, and economic sustainability.

\section{Data and methods}

\section{Data and sample}

The 2016 national survey was conducted with a probabilistic, geographically stratified and multi-stage sample ( $\mathrm{n}=2170$; four stages: suburb, square, house and person) including adults over 18 years of age, Chileans or foreigners living in the country for at least five years, distributed over the 111 urban municipal areas of the 15 regions of Chile. The sample was weighted using a raking technique, adjusting to sex, age and region, using demographic data from the National Statistics Institute (INE, 2005) and educational level data from the National Employment Survey [NENE] (INE, 2016). The survey's structured questionnaire consisted of 210 variables and 13 scales. Items were designed on the basis of previous studies (Leviston et al., 2014) and an analysis of the Chilean context on this issue. The survey was conducted at the respondents' households between June and July 2016 with a +/- 2.1\% margin of error and a $95 \%$ confidence interval.

\section{Variables and measures}

We identified the most relevant variables available in the database to explain the complex interactions between attitudes, values, beliefs, norms and behaviors toward the environment, following the theories and models generally used in the literature on these issues (Hornsey et al., 2016; Ajzen, 1991; Stern et al., 1999; Schwartz, 1977), and those used in the audience segmentation studies mentioned above. We selected independent variables that theoretically provide specific information for each of these dimensions. These variables present low statistical associations between them, which confirms their particular contribution to the model.

Both the size of the sample and the assumptions of the model allowed working with this wide set of variables. To validate and complement the description of each group, we resorted to a set of dependent variables that did not participate in the construction of the clusters. Both the independent and dependent variables are categorical. This is because these types of variables 
Rodolfo Jorge Patricio Sapiains Arrué, Gabriela Alejandra Azócar de la Cruz, Ana María Ugarte Caviedes y Javier Alberto Romero Hernández. Chileans, climate change and the natural environment: An audience segmentation study

allow more adequate and clearer operationalizations. This was considered when choosing the distance measure that we used to construct the cluster. The variables included in the analysis and their operationalization are shown in Table $1 .^{2}$

Beliefs about climate change: The overwhelming scientific consensus that indicate climate change is actually occurring does not necessarily ensures the acceptance of this fact by society. Therefore, a core component of this type of study is to identify core beliefs about the existence of climate change (Leiserowitz et al., 2015; Hine et al., 2013; Metag, 2015). Similarly important is the perception on what causes climate change. However, due to methodological restrictions, this aspect is integrated into the second part of the study.

Climate change concern: Concern about environmental deterioration and its multiple impacts has frequently been studied in environmental psychology and sociology (Dunlap et al., 2000) and included in numerous surveys on climate change (Leviston et al., 2014; Pew Research Center, 2015), as well as in audience segmentation studies (Leiserowitz et al., 2015; Hine et al., 2013; Metag, 2015).

Environmental worldviews: The complex interaction between people and the environment has been the focus of diverse studies to identify the relative importance of protecting nature within a context of major technological development, a global social system built upon the idea of unlimited economic progress, and a growing environmental awareness associated with the ongoing environmental crisis (Dunlap and Van Liere, 1978; Dunlap et al., 2000; Stern et al., 1995; Stern et al., 1999; Kahan et al., 2012; Heath and Gifford, 2006).

Perception of efforts to protect the environment: How people perceive their own performance compared to others is relevant considering that psychological phenomena such as the "better than average effect" (Bergquist, 2020) or the "self-serving bias" (Kriss et al., 2011; Hansman and Steimer, 2017) have been identified as psychological barriers to adaptation (Gifford, 2011).

Climate change-related behaviors: Belief in climate change or the degree of concern in facing the problem, which in spite of being important do not guarantee behavioral responses. Therefore, asking about specific climate actions is important in this type of studies. Actions can be related to either mitigation (aimed at reducing emissions of greenhouse gasses or enhancing carbon sinks) or adaption (i.e., the process of adjusting to actual or expected climate changes and its effects) (IPCC, 2014).

2 All tables are at the Annex, at end of this article. 
Perception of control: Another component of environmental psychology studies is how people perceive the possibility of tackling climate change (Hornsey et al., 2016; Ajzen, 1991; Stern et al., 1999).

For the second part of our study, we tested the following dependent variables (operationalization in Table 2):

Socio-economic level (SEL): Participants were grouped in three segments based on Chile's criteria considering family income, household head's occupation and schooling level (C1-2: highest level; C3: Middle-level; D-E: lowest level).

Age: Participants were organized into four age groups (18-30; 31-45; 46-60; 61+).

Level of education: Participants were organized into three categories (Less than secondary completed; complete secondary; incomplete university degree, graduate, postgraduate).

Climate change causes: One of the most salient dimensions of climate change beliefs is related to its causes. As previously noted, the scientific consensus on anthropogenic climate change is not clearly reflected in public opinion with an important proportion of people in countries such as the US and Australia thinking climate change is either a natural process or not happening at all.

Consumer buying behavior: We included questions related to the importance of the environment on specific consumption-related behaviors.

Climate change-related emotions: Complementary to environmental concern, emotional responses to climate change were included.

Climate change impacts: This factor includes questions about social dimensions that climate change might affect and also its potential positive impacts.

\section{Data analysis}

An agglomerative hierarchical classification model was used; it is an exploratory technique to identify groups that present differentiated behaviors from a set of independent variables. A typology with 32 variables was constructed to represent the dimensions addressed in the survey and Ward's method was applied to generate internally homogeneous groups (Hair et al., 2013; King, 2015; Mirkin, 2013). Since the variables were categorical, $\mathrm{chi}^{2}$ was used as a measure of distance. It should be noted that initially, we worked with a Latent Class Analysis that resulted in a typology of three groups, similar to that obtained with the hierarchical classification 
Rodolfo Jorge Patricio Sapiains Arrué, Gabriela Alejandra Azócar de la Cruz, Ana María Ugarte Caviedes y Javier Alberto Romero Hernández. Chileans, climate change and the natural environment: An audience segmentation study

model. The results of the latent class analysis, however, showed two groups with similar behaviors in a wide set of variables. Because of that, and following Metag et al. (2015), we opted to use Ward's method and the elbow criterion to find the best solution.

We notice 3 clearly different groups in their opinions and behaviors. To describe the typology, we used cross-tables, analyzing the distribution of the 33 variables within each group, comparing the results and using measures of association. We then analyzed how the dependent variables, including socioeconomic status, age, education level, and sex were distributed within each group. The only variable that did not present a statistical association with the typology was sex; all the other dependent variables show different results in each group. This helps to validate the identified model and to complement the description of the particularities of each group.

\section{Results and discussion}

\section{Typology}

Three groups were identified as G1: Pragmatists (people who think or act giving priority to practical considerations associated with a combination of economic, social and environmental worldviews); G2: Neoliberals (people who think or act giving priority to economic progress and individual freedom); and G3: Environmentalists (people who think or act giving priority to the environment over any other consideration and express traditional environmental worldviews). Notably, although each group has its own characteristics, the three groups' opinions on key climate change aspects did not vary significantly. Overall, participants are likely to believe that climate change is occurring (G1: 88.3\%, G2: 86.1\%, G3: 98.6\%) and report high levels of concern, although the Neoliberals showed a lower percentage regarding the latter $74.3 \%$ compared to $82 \%$ for Pragmatists and $100 \%$ for Environmentalists). The three groups identified climate change as a very important issue; nevertheless, among Neoliberals just $63.9 \%$ identified it as such, while Pragmatics and Environmentalists $77.7 \%$ and $95.1 \%$ did so, respectively.

These results show consensus among the general population on key aspects of climate change, which aligns with perceptions found in many other developing and developed countries (Newman et al., 2020). Similarly, most people within each group agree that consumerism threatens nature, that protecting the environment safeguards the wellbeing of human 
beings, that climate change is an opportunity to collectively build a fairer society, that the balance of nature is fragile, and that it is our duty to preserve it (Table 3). Therefore, it seems clear that climate change is not a bipartisan political issue in Chile as it is in the US or Australia. This is also relevant considering that Chileans have been historically divided between traditional right- and left-wing positions on many other social problems such as abortion, same-sex marriage and gender identity (CADEM, 2019; Criteria, 2018).

Along the same lines, only a small proportion of people believes technology will solve the environmental crisis, suggesting that technooptimism does not have much support in Chile at least to deal with climate change. However, a very high proportion in all groups believe schools are making their best effort to care for the environment and doing much better than the government, companies, people in general, and even themselves (Table 3). This might indicate that environmental education in Chile is having a positive impact on children and through them on their families, or that children are educating their parents on environmental issues and increasing climate change awareness as shown by Lawson et al. (2019) in the US. Albeit, more research is needed.

Below, common beliefs among the three groups identified (Pragmatists, Neoliberals, and Environmentalists) are described in detail.

\section{Group 1: Pragmatists}

This group represents $66.5 \%$ of the sample. Most people in this group believes climate change is occurring or will happen sometime in the future. This group contains the smallest proportion of individuals who agree that other people are doing their best to take care of the environment $(31.2 \%)$ while having a far more positive view of themselves (71.3\%). These results indicate that the majority of the country's population behaves and thinks in a similar way; which is consistent with the results of a research on the perception of climate change in Latin America, in which it is verified that the majority of the population believes in the existence of climate change, but only take some actions to face it (Azócar et al., 2020). Similarly, they evaluate the government and companies poorly, suggesting a "better than average effect" in the assessment of their own performance (Bergquist, 2020) or some kind of self-serving bias as environmental problems might be attributed to the weak efforts made by the others and not by themselves (Kriss et al., 2011; Hansman and Steimer, 2017). In both cases, these effects are important as they might become psychological barriers for the 
Rodolfo Jorge Patricio Sapiains Arrué, Gabriela Alejandra Azócar de la Cruz, Ana María Ugarte Caviedes y Javier Alberto Romero Hernández. Chileans, climate change and the natural environment: An audience segmentation study

implementation of more ambitious adaptation actions (Gifford, 2011). Also, this low evaluation of what other people, companies and the government are doing to protect the environment compared with their own performance might make them believe they are doing enough or implementing the best responses without actually being aware of the effects of their behaviors - beliefs that could generate an asymmetry between their intentions and the ultimate and cumulative impact of their actions (Whitmarsh, 2009).

Pragmatists seek to contribute personally to face climate change mainly through energy-saving behaviors that are generally simple to implement and, although important, not necessarily associated with deeper lifestyle changes (Gifford et al., 2011; Whitmarsh, 2009). Saving energy generally means saving money; then, the main driver of these actions might be economic gain (Howell et al., 2016; Scannell and Gifford, 2013; Bain et al., 2012). Moreover, considering that nearly $62 \%$ believe climate change is beyond their control and $40.1 \%$ that nothing they can do will solve the problem, this suggests that many people within this group implement these actions for reasons other than contributing to tackling climate change. A much lower, but still important proportion of Pragmatists (19.4\%) indicate they have a vegetable garden, an activity that is more demanding and has mid or long term benefits. Implementing this type of action might seem contradictory with the above suggesting a greater commitment to the environment. It also raises the question of a potential spillover effect (Nash et al., 2019); that is to say, engaging in one activity can, under certain circumstances, make it more likely to engage in other actions conducing to the same goal. Some people within this group might have a growing interest in improving their own environmental contribution as they implement more day-to-day actions. Future studies might explore this possibility along with an analysis of lifestyle changes on a more comprehensive range of climate-related actions and measures.

Pragmatists indicate they are against prioritizing economic goals over environmental goals, including the creation of jobs. They consider that caring for the environment will help to build a fairer society. The vast majority in this group agree that protecting the environment should be the main priority of the country as nature is fragile and vulnerable to industrialization. Also, a smaller though significant proportion within this group agrees that protecting the environment will help to defeat inequality and overcome poverty. Overall, these results suggest that people in this group do care for the environment, probably because of a combination of economic, social and environmental values. 


\section{Group 2: Neoliberals}

This group represents $26.5 \%$ of the sample. As the Pragmatics, Neoliberals are likely to believe climate change is occurring or will happen sometime in the future. This group presents the largest proportion of participants who positively evaluate the efforts made by both the government and companies, although that proportion is only $38.4 \%$ and $30.6 \%$ respectively. They are likely to believe they are doing better than other people, but in a smaller proportion than in the other two groups. They more frequently agree that climate change is beyond their control (64.6\%) and that nothing they can do will solve the problem (51.8\%). Consistently, Neoliberals are less likely to implement climate-related actions, despite almost half of them states they take short showers, uses low-energy lightbulbs, buys products in returnable or reusable packaging, and avoids leaving lights on in unoccupied environments: actions that are not too disruptive for traditional lifestyles and, generally, have an immediate economic benefit. On the contrary, a very small proportion of individuals in this group uses low-energy appliances, has a vegetable garden at home, or participates in community gardens.

This group presents the largest proportion of people who thinks economic and development goals are more important than the environment; however, this belief represents just between $50 \%-60 \%$ of the segment, which suggests that the environment is not totally secondary to the economy for them. Besides, more than a half agree that protecting the environment will help defeat inequality and overcome poverty. Similarly, a very high proportion (over $80 \%$ ) believes the main reason to protect the environment is to safeguard the wellbeing of human beings, that caring for the environment is an opportunity for people to work together for a fairer world, and that the environmental balance is fragile and it is our duty to preserve it. As well, most people within this group believes consumerism threatens nature and that taking care of nature should be the main priority for the country. Only $38.8 \%$ agrees that the government should not place environmental barriers on industrial development, while nearly $38 \%$ expresses some technooptimism in the face of climate change. Finally, $61.3 \%$ believes people should be free to choose the lifestyle they want regardless of its consequences for the environment.

Overall, this group holds more economy-oriented and individualistic values than the other two groups: economic progress and freedom to choose are generally more important than environmental regulations. However, the small proportion of people with a good evaluation of companies and 
government's efforts to protect the environment along with the low support for the elimination of environmental barriers for industrial development, among other results, suggest the existence of fundamental contradictions within this group. In advancing an interpretation for this, the Chilean context should be considered. Since the 70 s, the country has been built upon extractivism and radical neoliberalism, first imposed by the military dictatorship and then consolidated by both the progressivist and right-wing governments that have alternated in power since the early 90s (Ruiz, 2019; Moulian, 1997). As such, Chilean environmental regulations are not as strict as in most OECD countries (OECD and UN ECLAC, 2016), and there are numerous socio-environmental conflicts throughout the territory straining economic, social and environmental initiatives (Bolados, 2016; INDH, 2018; Maillet and Albala, 2018). In this scenario, the relatively low proportion of people opposing more "green tape" in this group might reflect the fact that in Chile such regulations are so weak that they are perceived as seriously jeopardizing the environment, increasing social tensions and/or making the country less competitive in the global market.

\section{Group 3: Environmentalists}

This group represents $7 \%$ of the sample. Virtually, all Environmentalists (98.6\%) believe climate change is occurring or will happen sometime in the future. They have the most negative evaluation of what the government and companies are doing to protect the environment, at once they have the most positive perception of other people and themselves (being them better than the others). They are likely to have a high perception of control, just $13 \%$ believes climate change is beyond their control while $11.5 \%$ says nothing they can do will solve the problem; this is one of the most important differences with the other two groups. Consistently, they present the highest percentages implementing climate-related actions, even though just $41.2 \%$ has a vegetable garden and $52.3 \%$ buys products in returnable or reusable packaging.

Overall, this group represents a more traditional ecocentric view or green perspective strongly opposing neoliberalism, or at least the Neoliberalism that prevails in Chile. For them, the environment is consistently more important than the economy, and its protection should be a national priority (100\%). They strongly believe nature's balance is fragile, and it is our duty to protect it. As they do not believe in nature's ability to recover from industrialization, they strongly disagree with eliminating environmental barriers to regulate industry. 
They do not believe in technological development as a solution to climate change, and they are very likely to disagree with the freedom to choose any lifestyle without considering its environmental consequences. This group also associates environmental protection with people's wellbeing, although the vast majority do not believe that caring for the environment will contribute to reducing inequality and overcoming poverty. This decoupling of the environment from equality and poverty might be explained by the growing awareness of structural problems in Chilean society that are behind massive social inequality, where the distribution of wealth is one of the main factors. In this sense, in the long-term and from a more global perspective, they are likely to believe that protecting the environment is an opportunity to build a fairer society, but specifically in Chile, defeating inequality and poverty would demand far more than environmental transformations alone.

\section{The typology and other climate change-related dimensions}

In the second part of this study, we analyzed how other variables behave in relation to the typology. Below, we present the results for each segment (Tables 4 and 5).

\section{Pragmatics}

Respondents in this group are widespread in all socio-economic groups, with a higher proportion of people over 46 than the other two groups, and with a level of education lower than Environmentalists, but slightly higher than Neoliberals. Most believe that climate change is caused totally or partially by human activities (93.7\%). The majority is concerned about the impact of their consumer-buying behaviors: slightly over a half knows the environmental impacts of some or all of the products they consume daily, and $33.8 \%$ would like to know more about those impacts. Also, a third affirms they know information about the environmental impact is labeled on some or all the products they buy, whereas another third has not noticed it, and the other third states they would like it to appear.

Furthermore, the majority (87.2\%) states that if a product is shown to harm the environment, they would stop buying it. In a similar vein, most would like to install solar panels in their homes, but have not done so mainly because they cannot afford it. More than a half believes climate change will bring no positive consequences, whereas $29 \%$ believes it will bring greater environmental protection. Finally, Pragmatics mention concern, fear and 
Rodolfo Jorge Patricio Sapiains Arrué, Gabriela Alejandra Azócar de la Cruz, Ana María Ugarte Caviedes y Javier Alberto Romero Hernández. Chileans, climate change and the natural environment: An audience segmentation study

sadness as the most salient emotional associations with climate change. Overall, these results confirm the main characteristics of this segment, showing that this group does care for the environment and would likely be keen on doing more if there were more opportunities or the conditions were more accessible.

\section{Neoliberals}

The largest proportion of this group is in the lowest socio-economic segment in the youngest interval (though they are widespread throughout the age groups), and overall they have the lowest level of education. They are likely to believe climate change is caused totally or partially by human activities (92\%). Only 33\% know the environmental impacts of the products they consume daily, or about the environmental information on the labels of the products they buy; however, most show a willingness to implement more environmentally aware behaviors and $75 \%$ affirms that they would stop buying a product if it is shown to be harmful to the environment. As the Pragmatists, they have not installed solar panels in their homes because they do not have the money to. Nearly $60 \%$ does not see positive consequences in climate change, while $18.5 \%$ mentions greater national unity, and $16.3 \%$ greater protection of the environment. Finally, they associate climate change mainly with concern, fear and anger. As mentioned in the description of this group, despite their focus on the economy and individual freedom, this segment does show interest in environmental issues.

\section{Environmentalists}

Overall, the lower proportion of people in this group (7\%) might be explained by its strong association with the highest education and socioeconomic levels, which in turn, is linked to the high levels of inequality and social segregation in Chile. In point of fact, a larger proportion of Environmentalists is in the highest socioeconomic groups, as well as in the 31-45 age range (overall it includes the youngest people), and the ones with the highest education level. Although they account for the largest proportion of people who agree human action alone is the main cause of climate change $(70.6 \%)$, they also have the largest proportion of individuals who believe climate change is explained by natural processes (19.5\%).

Overall, $80.5 \%$ believes it is caused totally or partially by human activities, which is surprisingly lower than in the other two groups. In terms 
of consumer behavior, they have not installed solar panels mainly because they cannot afford it (as the other groups, though at a higher proportion, $80.6 \%)$. Similarly, this group shows the largest proportion of people who see no positive consequences from climate change (90.9\%). Finally, this group associates climate change mainly with concern, fear and sadness.

The significant proportion of people in this group who believes climate change is caused by natural processes is puzzling, especially considering the consistent ecocentric views in all the other items. One possible interpretation is that for this group the natural cycles of the Earth are considered central in their worldviews and interpret climate change as such. This is not denying the problem, but the capacity of humans to generate changes of such magnitude. Regardless the causes, people in this group agree that more has to be done in order to protect the environment; in practical terms, this means that believing climate change is either a natural phenomenon or caused by human action does not seem to limit their pro-environmental behaviors. Also, this is only a subgroup within the $7 \%$ of the total sample, which shows the importance of understanding in-depth the perspectives of this segment in future studies with a wider sample of environmentalists.

\section{Targeted Communication Strategies}

\section{Pragmatists}

Given that this segment does care for the environment and would likely be keen on doing more were there more opportunities or the conditions more accessible, the communication strategies that might be most useful for this group should consider making the efforts of other actors (government, companies and people in general) on climate change visible, as well publicizing their actions and highlighting the most effective. In this way, Pragmatists will be able to appreciate that more people are committed to the challenge of facing climate change and protecting the environment. At the same time, they will learn about new actions they could incorporate into their repertoire. Furthermore, it is important to consider that any recommendations to increase the participation of Pragmatists in tackling climate change will be more convincing within an adaption plan that considers all the stakeholders, with clear collective objectives and strategies in order to achieve them. 
Rodolfo Jorge Patricio Sapiains Arrué, Gabriela Alejandra Azócar de la Cruz, Ana María Ugarte Caviedes y Javier Alberto Romero Hernández. Chileans, climate change and the natural environment: An audience segmentation study

\section{Neoliberals}

For most Neoliberals, the environment is important and cannot be ignored; this in turn might lead to an open discussion and support for stricter environmental regulations and more ambitious climate change responses. For a significant proportion within this group, environmental issues, in general, and climate change, in particular, are starting to have a positive impact on how nature is perceived. This is consistent with the diverse and sometimes antagonist approaches to the climate crisis that Chilean and foreign companies are demonstrating in Chile. While some are making effective changes in their productive processes, interacting with the scientific community, organizing themselves to reach the Nationally Determined Contributions (NDC) and implementing adaptation strategies (www.accionempresas.cl; www.clgchile.cl), ${ }^{3}$ others are still involved in multiple socio-environmental conflicts due to non-environmentally friendly practices, especially extractivist activities with serious environmental and social impacts (INDH, 2018).

These results suggest that the view of those showing growing environmental engagement might be starting to prevail. Thus, rather than trying to convince Neoliberals about the importance of climate change, further communication strategies should integrate the experiences and views of the economic groups that are already transforming their understanding of the relation between economy and environment with a view to a more sustainable future. Furthermore, for this group it would be important to highlight that actions implemented in this line do not seek to limit individual freedoms, but rather to build a safer and more resilient environment. Also, although the majority within this group do not perceive potential positive consequences from climate change, there is a segment that does (i.e., greater national unity and greater protection of the environment) and highlighting positive consequences might be useful when designing communication strategies targeting this group.

Finally, by recognizing the importance of environmental and climate change education in public schools, this sector would probably be receptive to the message that children can disseminate to their parents on how to face climate change at home.

3 http://clgchile.cl/noticias/17-04-2020/declaracion-publica-lideres-empresariales-porla-accion-climatica-apoyan-la-ndc-de-chile-y-se-comprometen-a-impulsarla 


\section{Environmentalists}

The size of this group (only $7 \%$ of the sample) demonstrates that this viewpoint has not filtered evenly throughout the community but remains encapsulated in a small group with the highest socioeconomic and education levels. This group represents those already convinced that climate change needs to be addressed and who are apparently taking actions to do so. Communication strategies for this group might focus on harnessing their energies into those actions that are more effective, providing adequate feedback and avoiding green consumerism. Finally, as this group presents the highest income, more might be done to encourage personal financial contributions to support environmental education especially for public schools in low-income suburbs.

This could be a powerful use of the Environmentalists' enthusiasm as recent studies conducted in Chile with children and adolescents (Defensoría de la Niñez, 2020) showed that protecting the environment and taking care of animals are their main priorities; which also reinforces the idea that schools are doing a great job in environmental education becoming drivers of a generational change toward more responsible relationships between people and the environment and potentially increasing the proportion of population that will fall into this group in the future, something that should be appealing for this group.

\section{Conclusion}

This study aimed at identifying different groups within the Chilean society regarding climate change. The analysis generated three groups: Pragmatics (66.5\%), Neoliberals (26.5\%) and Environmentalists (7\%). Most people within these groups believe climate change is important, is happening or will happen in the future, and is an issue of high concern, showing that the country is not polarized on this matter. This strong level of consensus might facilitate the implementation of more ambitious responses to both mitigation and adaptation to climate change. Differences between the groups were mainly found on worldviews, behaviors, perceptions of efforts to protect the environment and perception of control.

The second part of the study showed that in general the segments do vary in relation to sociodemographic characteristics (i.e., age, socio-economic level, education), perceptions of climate change causes, consumer buying behaviors, perceptions of climate change impacts and emotional responses to 
climate change. Overall, more significant differences appear when comparing Environmentalists with the other two groups, especially in the assessment of others' efforts to protect the environment, the perception of human control over climate change, and some environmental worldviews.

In terms of limitations, despite that a longitudinal study in Australia showed no major changes in climate change perceptions in the local population for the period 2010-2014 (Leviston et al., 2015), the fact that the data is from 2016 might be deemed problematic. Similarly, using secondary data might also constitute a limitation. However, it is important to notice that these results constitute a first approach to understand the particular complexities of the relationship Chileans establish with climate change and the natural environment. Thus, this research can be used to organize further segmentation studies and analyses to encourage higher levels of engagement with climate action in the Chilean population and other Latin American countries, as well it may also be a baseline to measure how climate change perceptions might vary over time.

Finally, this research provides ideas on how differentiated communication strategies might be used to target these distinct perspectives on climate change. As such, we hope this study can contribute to craft messaging and policies that are more effective in reaching these distinct segments of the Chilean population to encourage higher levels of engagement with climate action.

\section{References}

Ajzen, Icek (1991), "The theory of planned behavior", in Organizational Behavior and Human Decision Processes, vol. 50, no. 2, USA: Academic Press Elsevier Science.

Azócar, Gabriela et al. (2921), "Climate change perception, vulnerability, and readiness: inter-country variability and emerging patterns in Latin America”, in Journal of Environmental Studies and Sciences, vol. 11, USA: Springer Nature.

Bain, Paul et al. (2012), "Promoting pro-environmental action in climate change deniers", in Nature Climate Change, vol. 2, England: Nature Research.

Bergquist, Magnus (2020), "Most People Think They Are More Pro-Environmental than Others: A Demonstration of the Better-than-Average Effect in Perceived ProEnvironmental Behavioral Engagement", in Basic and Applied Social Psychology, vol. 42, no. 1, USA: Taylor \& Francis.

Bertoldo, Raquel et al. (2019), "Scientific truth or debate: On the link between perceived scientific consensus and belief in anthropogenic climate change", in Public Understanding of Science, vol. 28, no. 7, England: Sage. 
Convergencia Revista de Ciencias Sociales, vol. 28, 2021, Universidad Autónoma del Estado de México

Bolados, Paola (2016), "Conflictos socio-ambientales/territoriales y el surgimiento de identidades post neoliberales (Valparaíso-Chile)”, in Izquierdas, vol. 31, Chile: Ariadna Ediciones \& Saint Petersburg State University.

Burck, Jan et al. (2019), Indice de Desempeño frente al Cambio Climático. Resultados 2020. Climate Action Network (CAN), Germanwatch and New Climate Institute. Available at: www.climate-change-performance-index.org [14th, December, 2020].

CADEM (2019), Encuesta Plaza Pública. Cuarta semana de Agosto - Estudio n²93. Available at: https://www.cadem.cl/wp-content/uploads/2019/08/Track-PP-293Agosto-S4-VF.pdf [16th, December, 2020].

Cook, John et al. (2016), "Consensus on consensus: a synthesis of consensus estimates on human-caused global warming”, in Environmental Research Letters, vol. 11, no. 4, England: Institute of Physics.

Cook, John et al. (2013), "Quantifying the consensus on anthropogenic global warming in the scientific literature", in Environmental Research Letters, vol. 8, no. 2, England: Institute of Physics.

Corner, Adam et al. (2012), "Uncertainty, scepticism and attitudes towards climate change: biased assimilation and attitude polarisation", in Climatic Change, vol. 114, Netherlands: Springer.

Criteria (2018), Agenda ciudadana criteria. Available at: https://www.criteria.cl/wpcontent/uploads/2019/05/Agenda-Agosto2018.pdf [16th, December, 2020].

Defensoría de la Niñez (2020), Estudio de opinión niños, niñas y adolescentes 2019. Levantamiento en hogares. Available at: https://www.defensorianinez.cl/homeadulto/estudios-y-estadisticas/ [26th, August, 2020].

Detenber, Benjamin et al. (2016), "Audience Segmentation for Campaign Design: Addressing Climate Change in Singapore", in International Journal of Communication, vol. 10, USA: University of Southern California.

Dunlap, Riley and Van Liere, Kent (1978), "The new environmental paradigm: A proposed measur-ing instrument and preliminary results", in Journal of Environmental Education, vol. 9, USA: Taylor \& Francis.

Dunlap, Riley et al. (2000), "Measuring endorsement of the new ecological paradigm: a revised NEP scale”, in Journal Social Issues, vol. 56, no. 3, USA: Wiley.

Gifford, Robert (2011), "The Dragons of Inaction Psychological Barriers That Limit Climate Change Mitigation and Adaptation", in American Psychologist, vol. 66, no. 4, USA: American Psychological Association.

Gifford, Robert et al. (2011), "Behavioral dimensions of climate change: drivers, responses, barriers, and interventions", in WIREs Climate Change, vol. 2, no. 6, England: Wiley.

Global Carbon Proyect (2018), Global carbon atlas. Available at: http://www. globalcarbonatlas.org/en/CO2-emissions [26th, August, 2020].

Hair, Joseph et al. (2013), Multivariate data analysis, Scotland: Pearson.

Hansmann, Ralf and Steimer, Nora (2017), "Subjective reasons for littering: A self-serving attribution bias as justification process in an environmental behaviour model", in Environmental Research, Engineering and Management, vol. 73, no.1, Lituania: Kaunas University of Technology (KTU)

Heath, Yuko and Gifford, Robert (2006), "Free-Market Ideology and Environmental Degradation: The Case of Belief in Global Climate Change", in Environment and Behavior, vol. 38, no. 1, USA: Sage. 
Rodolfo Jorge Patricio Sapiains Arrué, Gabriela Alejandra Azócar de la Cruz, Ana María Ugarte Caviedes y Javier Alberto Romero Hernández. Chileans, climate change and the natural environment: An audience segmentation study

Hine, Donald et al. (2013) "Identifying climate change interpretive communities in a large Australian simple", in Journal of Environmental Psychology, vol. 36, England: Academic Press.

Hornsey, Matthew et al. (2016), "Meta-analyses of the determinants and outcomes of belief in climate change", in Nature Climate Change, vol. 6, England: Nature Research.

Howell, Rachel (2016), "It's not (just) 'the environment, stupid!' Values, motivations, and routes to engagement of people adopting lower-carbon lifestyles", in Global Environmental Change, vol. 23, no. 1, England: Elsevier Academic Press.

Howell, Rachel et al. (2016), "Impacts of adaptation and responsibility framings on attitudes towards climate change mitigation", in Climatic Change, vol. 136, Netherlands: Springer.

INDH [Instituto Nacional de Derechos Humanos] (2018), Mapa de conflictos socioambientales en Chile. Available at: https://mapaconflictos.indh.cl/\#/ [26, August, 2020].

INE [Instituto Nacional de Estadísticas] (2005), "Clasificación socioeconómica de hogares de Chile”, in Enfoque estadístico, Chile: Instituto Nacional de Estadísticas.

INE [Instituto Nacional de Estadísticas] (2016), Encuesta Nacional de Empleo 2016. Available at: http://webanterior.ine.cl/estadisticas/laborales/ene [26th, August, 2020].

IPCC [Intergovernmental Panel on Climate Change] (2014), Climate Change 2014: Synthesis Report. Contribution of Working Groups I, II and III to the Fifth Assessment Report of the Intergovernmental Panel on Climate Change, Switzerland: Geneva.

Kahan, Dan et al. (2012), "The polarizing impact of science literacy and numeracy on perceived climate change risks", in Nature Climate Change, vol. 2, England: Nature Research.

King, Ronald (2015), Cluster Analysis and Data Mining: An Introduction, USA: Mercury Learning and Information.

Kriss, Peter et al. (2011), "Behind the veil of ignorance: Self-serving bias in climate change negotiations", in Judgment and Decision Making, vol. 6, no. 7, USA: Society for Judgment and Decision Making.

Lawson, Danielle et al. (2019), "Children can foster climate change concern among their parents", in Nature Climate Change, vol. 9, England: Nature Research.

Leiserowitz, Anthony et al. (2015), Global Warming's Six Americas, March 2015, USA: Yale University and George Mason University.

Leviston, Zoe et al. (2014), Fourth annual survey of Australian attitudes to climate change: Interim report, Australia: Commonwealth Scientific and Industrial Research Organisation.

Leviston, Zoe et al. (2015), Australian attitudes to climate change and adaptation: 20102014, Australia: Commonwealth Scientific and Industrial Research Organisation.

Maibach, Edward et al. (2011), "Identifying Like-Minded Audiences for Global Warming Public Engagement Campaigns: An Audience Segmentation Analysis and Tool Development", in PLoS ONE, vol. 6, no. 3, USA: Public Library Science.

Maillet, Antoine and Albala, Adrián (2018), "Conflictos socioambientales en los proyectos eléctricos en Chile (2005-2016): Un análisis configuracional”, in América Latina Hoy, vol. 79, Spain: Universidad de Salamanca.

Marlon, Jennifer et al. (2019), Yale Climate Opinion Maps. U.S. 2019. Available at: https:// climatecommunication.yale.edu/visualizations-data/ycom-us/ [26th, August, 2020]. 
Convergencia Revista de Ciencias Sociales, vol. 28, 2021, Universidad Autónoma del Estado de México

MacCright, Aron et al. (2015), "Political ideology and views about climate change in the European Union”, in Environmental Politics, vol. 25, England: Taylor \& Francis.

Metag, Julian et al. (2015), "Global warming's five Germanys: A typology of Germans' views on climate change and patterns of media use and information", in Public Understanding of Science (Bristol, England), vol. 26, no. 4, England: Sage.

Mirkin, Boris (2013), Clustering: a data recovery approach, USA: Taylor \& Francis.

Moulian, Tomás (1997), Chile actual: Anatomia de un mito, Chile: LOM-Arcis.

Nash, Nick et al. (2019), "Reflecting on Behavioral Spillover in Context: How Do Behavioral Motivations and Awareness Catalyze Other Environmentally Responsible Actions in Brazil, China, and Denmark?", in Frontiers in Psychology, vol. 10, Switzerland: Frontiers Media.

Newman, Todd et al. (2018), "Climate change, cultural cognition, and media effects: Worldviews drive news selectivity, biased processing, and polarized attitudes", in Public Understanding of Science, vol. 27, no. 8, England: Sage.

Newman, Nic et al. (2020), Reuters Institute Digital News Report 2020. Available at: https:// reutersinstitute.politics.ox.ac.uk/sites/default/files/2020-06/DNR_2020_FINAL. pdf [16th, December, 2020].

OECD [Organisation for Economic Co-operation and Development] and UN ECLAC [United Nations Economic Commission for Latin America and the Caribbean] (2016), OECD Environmental Performance Reviews: Chile 2016, OECD Environmental Performance Reviews, France: Organisation for Economic Co-operation and Development Publishing.

Oficina de Cambio Climático (2014), Plan Nacional de Adaptación al Cambio Climático, Chile: Ministerio del Medio Ambiente.

Pasek, Josh (2018), "It's not my consensus: Motivated reasoning and the sources of scientific illiteracy”, in Public Understanding of Science, vol. 27, no. 7, England: Sage.

Pew Research Center (2015), Global Concern about Climate Change, broad support for limiting emissions. November. Available at: http://assets.pewresearch.org/wp-content/ uploads/sites/2/2015/11/Pew-Research-Center-Climate-Change-Report-FINALNovember-5-2015.pdf [16th, December, 2020].

Poortinga, Wouter and Darnton, Andrew (2016), "Segmenting for sustainability: The development of a sustainability segmentation model from a Welsh sample", in Journal of Environmental Psychology, vol. 45, England: Academic Press.

Ruiz, Carlos (2019), La politica en el neoliberalismo. Experiencias latinoamericanas, Chile: LOM.

Sapiains, Rodolfo et al. (2017), Encuesta Nacional de Medio Ambiente y Cambio Climático. Santiago de Chile: Ministerio del Medio Ambiente, CONICYT y CR2. Available at: http://www.cr2.cl/wp-content/uploads/2017/04/ENMA-Informe-2.pdf [16, December, 2020].

Scannell, Leila and Gifford, Robert (2013), "Personally Relevant Climate Change: The Role of Place Attachment and Local Versus Global Message Framing in Engagement", in Environment and Behavior, vol. 45, no. 1, USA: Sage.

Sherley, Chris et al. (2014), "Using Segmentation and Prototyping in Engaging PoliticallySalient Climate-Change Household Segments", in Journal of Nonprofit and Public Sector marketing, vol. 26, USA: Taylor \& Francis. 
Stern, Paul et al. (1999), "A value-belief-norm theory of support for social movements: The case of envi- ronmentalism", in Human Ecology Review, vol. 6, no. 2, Australia: Anu Press.

Stern, Paul et al. (1995), "Values, beliefs, and proenvironmental action: attitude formation toward emergent attitude objects", in Journal of Applied Social Psychology, vol. 25, USA: Wiley.

Schwartz, Shalom (1977), "Normative influences on altruism”, in Advances in experimental social psychology, vol. 10, no. 1, USA: Elsevier Academic Press.

Whitmarsh, Lorraine (2009), "Behavioural responses to climate change: Asymmetry of intentions and impacts", in Journal of Environmental Psychology, vol. 29, England: Academic Press.

Whitmarsh, Lorraine (2011), "Scepticism and uncertainty about climate change: Dimensions, determinants and change over time", in Global Environmental Change, vol. 21, England: Elsevier.

World Bank (2020), CO2 emissions (metric tons per capita) - Latin America \& Caribbean. Data.worldbank.org. Available at: https://data.worldbank.org/ indicator/EN.ATM.CO2E.PC? end=2014\&locations=ZJ\&most_recent_value_ $\operatorname{desc}=$ true\&start $=1960 \& v i e w=$ chart [26th, August, 2020]. 


\section{Table 1}

\section{Items used in the typology}

\begin{tabular}{|c|c|}
\hline Variables & Operationalization \\
\hline $\begin{array}{l}\text { Beliefs about } \\
\text { climate change }\end{array}$ & $\begin{array}{l}\text { Participants were asked if climate change is happening now or will } \\
\text { happen sometime in the future }(1) \text { or if they think climate change is } \\
\text { not really happening }(0) \text {. }\end{array}$ \\
\hline $\begin{array}{l}\text { Clin } \\
\text { con }\end{array}$ & $\begin{array}{l}\text { Participants were asked: How worried are you about climate change? } \\
\text { ( } 1=\text { A little to } 4=\text { Very concerned); How important is climate change } \\
\text { for you? ( } 1=\text { Not at all important to } 4=\text { Very important). }\end{array}$ \\
\hline $\begin{array}{l}\text { Env } \\
\text { wor }\end{array}$ & $\begin{array}{l}\text { Participants were asked their extent of agreement }(1=\text { Totally disagree } \\
\text { to } 4=\text { Totally agree) with } 15 \text { statements about the relation between } \\
\text { society and nature (regarding whether technological development, } \\
\text { social and economic progress, industrialization and/or jobs were } \\
\text { more important than protecting the environment, how fragile the } \\
\text { environment is, how important it is to protect it and the priority to } \\
\text { do so. }\end{array}$ \\
\hline $\begin{array}{l}\text { Perception } \\
\text { of efforts to } \\
\text { protect the } \\
\text { environment }\end{array}$ & $\begin{array}{l}\text { Participants were asked if the national government, private companies, } \\
\text { schools, people in general and themselves were doing their best to } \\
\text { protect the environment }(1=\text { Totally disagree to } 4=\text { Totally agree }) \text {. } \\
\text { The scale consists of } 5 \text { items and showed adequate levels of reliability } \\
\text { (Omega }=0.744) \text {. }\end{array}$ \\
\hline $\begin{array}{l}\text { Climate } \\
\text { change-related } \\
\text { behaviors }\end{array}$ & $\begin{array}{l}\text { Participants were asked whether they implemented the following } \\
\text { actions (1) or not }(0) \text { : } \\
\text { Do you take short showers? / Do you use low energy lamps? / Do } \\
\text { you use low-energy appliances? / Do you avoid leaving lights on in } \\
\text { unoccupied environments? / Do you wait for food to cool before } \\
\text { storing in the refrigerator? / Do you have a vegetable garden in your } \\
\text { home, or do you participate in community gardens? / Do you buy } \\
\text { products in returnable or reusable packaging? }\end{array}$ \\
\hline $\begin{array}{l}\text { Perception of } \\
\text { control }\end{array}$ & $\begin{array}{l}\text { To what extent do you agree with the following statements }(1=\text { Totally } \\
\text { disagree to } 4=\text { Totally agree): } \\
\text { The impacts of climate change are beyond my control. } \\
\text { Nothing I can do will solve climate change. }\end{array}$ \\
\hline
\end{tabular}

Source: Own elaboration based on the National Survey Environmental and Climate Change 2016, Chile. 
Rodolfo Jorge Patricio Sapiains Arrué, Gabriela Alejandra Azócar de la Cruz, Ana María Ugarte Caviedes y Javier Alberto Romero Hernández. Chileans, climate change and the natural environment: An audience segmentation study

\section{Table 2}

\section{Items used in the second part of the study}

\begin{tabular}{|c|c|}
\hline $\begin{array}{l}\text { Socio-economic level } \\
\text { (NSE) }\end{array}$ & $\begin{array}{l}\text { Participants were grouped in three segments based on } \\
\text { Chile's criteria to measure this which is result of family } \\
\text { income, and occupation and level of education of the head } \\
\text { of the household (C1-2: highest level; C3: Mid-level; D-E: } \\
\text { lowest level). }\end{array}$ \\
\hline Age & $\begin{array}{l}\text { Participants were organized into four age groups }(18-30 ; 31- \\
45 ; 46-60 ; 61+) \text {. }\end{array}$ \\
\hline Level of education & $\begin{array}{l}\text { Participants were organized into three categories (Less than } \\
\text { secondary completed; Secondary completed; University } \\
\text { degree completed, not completed, post graduate studies). }\end{array}$ \\
\hline Climate change causes & $\begin{array}{l}\text { Participants who believed climate change was occurring } \\
\text { or will occur sometime in the future were asked if climate } \\
\text { change was caused by human actions, natural processes or a } \\
\text { combination of both. }\end{array}$ \\
\hline \multirow[t]{7}{*}{$\begin{array}{l}\text { Consumer buying } \\
\text { behavior }\end{array}$} & $\begin{array}{l}\text { Do you know the impacts on the environment of the } \\
\text { products you consume on a daily basis? (I have not noticed } \\
\text { it; No, and I am not interested; No, but I would like to know } \\
\text { this; Yes of some products; Yes of all products). }\end{array}$ \\
\hline & $\begin{array}{l}\text { If a product is proven to harm the environment, would you } \\
\text { stop buying it? (Yes; No). }\end{array}$ \\
\hline & $\begin{array}{l}\text { On the products you buy, does information about their } \\
\text { environmental impact appear on the label? (No and I am not } \\
\text { interested; I have not noticed. / I don't read the labels; No, } \\
\text { but I would you like it to appear; Yes in some of them; Yes, } \\
\text { in all of them). }\end{array}$ \\
\hline & Regarding the installation of solar panels in your home: \\
\hline & $\begin{array}{l}\text { (I have not installed solar panels; I have installed solar panels; } \\
\text { I don't know what solar panels are). }\end{array}$ \\
\hline & Why haven't you installed solar panels? \\
\hline & $\begin{array}{l}\text { (I don't have the money to do it/ I live in a place where you } \\
\text { can't do it/ I don't know how to do it/ I am not interested/ } \\
\text { I do not see utility/ The investment is not worth it because } \\
\text { they are inefficient). }\end{array}$ \\
\hline $\begin{array}{l}\text { Climate change-related } \\
\text { emotions }\end{array}$ & $\begin{array}{l}\text { What feelings and /or emotions arise when you hear the } \\
\text { concept "climate change"? (open ended question). }\end{array}$ \\
\hline
\end{tabular}


Climate change impacts What positive consequences could climate change bring? (None; Greater protection of the environment; Greater social development / social equity / less inequality; Greater national unity; Greater economic growth).

To what extent do you agree with the following statements about climate change $(1=$ Totally disagree to $4=$ Totally agree): It will negatively affect the economy; It will increase migrations of people; It will make the price of energy more expensive; Food prices will rise; It will negatively affect people's daily lives; It will generate problems in people's health.

Source: Own elaboration based on the National Survey Environmental and Climate Change 2016, Chile.

Table 3

Results in the typology

\begin{tabular}{|c|c|c|c|}
\hline & G1: & G2: & G3: \\
\hline \multicolumn{4}{|c|}{ Perception of efforts to protect the environment ( $\%$ totally agree + agree) } \\
\hline $\begin{array}{l}\text { The Government is making its best effort to take care of the } \\
\text { environment }\end{array}$ & $27.5 \%$ & $38.4 \%$ & $7.1 \%$ \\
\hline $\begin{array}{l}\text { Companies are doing their best to take care of the } \\
\text { environment }\end{array}$ & $13.1 \%$ & $30.6 \%$ & $1.3 \%$ \\
\hline Schools are doing their best to care of the environment & $73.2 \%$ & $73.8 \%$ & $86.6 \%$ \\
\hline $\begin{array}{l}\text { People in general are doing their best to take care of the } \\
\text { environment }\end{array}$ & $31.2 \%$ & $48.9 \%$ & $61.1 \%$ \\
\hline I am doing my best to take care of the environment & $71.3 \%$ & $62.8 \%$ & $74.3 \%$ \\
\hline \multicolumn{4}{|l|}{ Perception of control (\% totally agree + agree) } \\
\hline The impacts of climate change are beyond my control & $61.8 \%$ & $64.6 \%$ & $13.2 \%$ \\
\hline Nothing I can do will solve climate change & $40.2 \%$ & $51.8 \%$ & $11.5 \%$ \\
\hline \multicolumn{4}{|l|}{ Actions (\% affirmative responses) } \\
\hline Do you take short showers? & $80.3 \%$ & $51.7 \%$ & $79.7 \%$ \\
\hline Do you use low energy lamps? & $91.4 \%$ & $51.2 \%$ & $100.0 \%$ \\
\hline Do you use low-energy appliances? & $76.4 \%$ & $8.2 \%$ & $97.5 \%$ \\
\hline $\begin{array}{l}\text { Do you avoid leaving lights on in unoccupied } \\
\text { environments? }\end{array}$ & $93.6 \%$ & $46.2 \%$ & $100.0 \%$ \\
\hline $\begin{array}{l}\text { Do you wait for the food to cool before storing in the } \\
\text { refrigerator? }\end{array}$ & $82.3 \%$ & $24.5 \%$ & $100 \%$ \\
\hline
\end{tabular}


Rodolfo Jorge Patricio Sapiains Arrué, Gabriela Alejandra Azócar de la Cruz, Ana María Ugarte Caviedes y Javier Alberto Romero Hernández. Chileans, climate change and the natural environment: An audience segmentation study

\begin{tabular}{|c|c|c|c|}
\hline $\begin{array}{l}\text { Do you have a vegetable garden in your home, or do you } \\
\text { participate in community gardens? }\end{array}$ & $19.4 \%$ & $6.9 \%$ & $41.2 \%$ \\
\hline Do you buy products in returnable or reusable packaging? & $59.9 \%$ & $52.6 \%$ & $52.3 \%$ \\
\hline
\end{tabular}

Importance of the environment relative to other social priorities (\% totally agree + agree)

\begin{tabular}{|c|c|c|c|}
\hline $\begin{array}{l}\text { Technological development alone will help to make climate } \\
\text { change no longer a problem. }\end{array}$ & $33.5 \%$ & $37.7 \%$ & $0.0 \%$ \\
\hline $\begin{array}{l}\text { The economic or social progress of a country is more } \\
\text { important than caring for the environment. }\end{array}$ & $32.7 \%$ & $53.1 \%$ & $1.8 \%$ \\
\hline $\begin{array}{l}\text { The environment has the capacity to adapt to the changes } \\
\text { generated by industrialization. }\end{array}$ & $25.8 \%$ & $47.5 \%$ & $1.3 \%$ \\
\hline $\begin{array}{l}\text { We have to worry more about creating jobs than protecting } \\
\text { the environment. }\end{array}$ & $34.6 \%$ & $58.8 \%$ & $3.5 \%$ \\
\hline $\begin{array}{l}\text { Protecting the environment will help reduce inequality } \\
\text { between rich and poor. }\end{array}$ & $40.6 \%$ & $55.6 \%$ & $9.9 \%$ \\
\hline Caring for the environment is key to overcoming poverty. & $59.6 \%$ & $57.8 \%$ & $14.7 \%$ \\
\hline $\begin{array}{l}\text { It is fair that poor countries industrialize to achieve } \\
\text { development even if it has negative consequences on the } \\
\text { environment. }\end{array}$ & $28.4 \%$ & $57.4 \%$ & $1.1 \%$ \\
\hline $\begin{array}{l}\text { People are free to choose the lifestyle they want regardless of } \\
\text { its consequences for the environment. }\end{array}$ & $37.0 \%$ & $61.3 \%$ & $7.1 \%$ \\
\hline $\begin{array}{l}\text { The government should not put environmental barriers on } \\
\text { the development of the industry. }\end{array}$ & $28.5 \%$ & $38.8 \%$ & $1.8 \%$ \\
\hline Consumerism threatens nature. & $89.3 \%$ & $70.7 \%$ & $94.2 \%$ \\
\hline $\begin{array}{l}\text { The main reason for protecting the environment is to } \\
\text { safeguard the wellbeing of humans. }\end{array}$ & $86.6 \%$ & $81.0 \%$ & $98.4 \%$ \\
\hline $\begin{array}{l}\text { Taking care of nature should be the main priority for the } \\
\text { country. }\end{array}$ & $84.2 \%$ & $65.3 \%$ & $100.0 \%$ \\
\hline $\begin{array}{l}\text { Caring for the environment is an opportunity for people to } \\
\text { work together for a fairer world. }\end{array}$ & $93.9 \%$ & $87.0 \%$ & $99.4 \%$ \\
\hline $\begin{array}{l}\text { The balance of the environment is fragile and it is our duty } \\
\text { to preserve it. }\end{array}$ & $97.0 \%$ & $86.2 \%$ & $100.0 \%$ \\
\hline $\begin{array}{l}\text { It is necessary to protect the environment even if this means } \\
\text { fewer sources of work. }\end{array}$ & $64.6 \%$ & $61.4 \%$ & $66.1 \%$ \\
\hline
\end{tabular}

Source: Own elaboration based on the National Survey Environmental and Climate Change 2016, Chile. 
Table 4

\section{Results of the second part of the study}

\begin{tabular}{|c|c|c|c|}
\hline & G1: & G2: & G3: \\
\hline \multicolumn{4}{|l|}{ Socio-economic level } \\
\hline $\mathrm{C} 1-2$ & $32.2 \%$ & $29.3 \%$ & $40.8 \%$ \\
\hline $\mathrm{C} 3$ & $35.4 \%$ & $34.3 \%$ & $48.1 \%$ \\
\hline D-E & $32.4 \%$ & $36.4 \%$ & $11.1 \%$ \\
\hline \multicolumn{4}{|l|}{ Age } \\
\hline $18-30$ & $25.9 \%$ & $35.2 \%$ & $13.7 \%$ \\
\hline $31-45$ & $30.4 \%$ & $26.1 \%$ & $57.1 \%$ \\
\hline $46-60$ & $26.7 \%$ & $23.9 \%$ & $22.1 \%$ \\
\hline $61+$ & $17.0 \%$ & $14.8 \%$ & $7.1 \%$ \\
\hline \multicolumn{4}{|l|}{ Level of education } \\
\hline Less than secondary completed & $34.7 \%$ & $41.1 \%$ & $10.9 \%$ \\
\hline Secondary completed & $31.5 \%$ & $29.1 \%$ & $41.7 \%$ \\
\hline $\begin{array}{l}\text { University degree completed, not completed, post } \\
\text { graduate degree }\end{array}$ & $33.8 \%$ & $29.8 \%$ & $47.4 \%$ \\
\hline \multicolumn{4}{|c|}{ What do you think is the main cause of climate change? } \\
\hline Human activity & $55.8 \%$ & $48.4 \%$ & $70.6 \%$ \\
\hline $\begin{array}{l}\text { The combination of human activity and natural } \\
\text { processes of the planet }\end{array}$ & $37.9 \%$ & $43.6 \%$ & $9.9 \%$ \\
\hline Natural processes of the planet & $6.3 \%$ & $8.0 \%$ & $19.5 \%$ \\
\hline
\end{tabular}

Do you know the impacts on the environment of the products you consume on a daily basis?

\begin{tabular}{llll}
\hline I have not noticed it & $8.5 \%$ & $22.9 \%$ & $15.2 \%$ \\
\hline No, and I am not interested & $3.2 \%$ & $9.7 \%$ & $0.0 \%$ \\
\hline No, but I would like to know this & $33.8 \%$ & $33.7 \%$ & $14.8 \%$ \\
\hline Yes, of some products & $45.6 \%$ & $30.7 \%$ & $51.8 \%$ \\
\hline Yes, of all products & $8.9 \%$ & $3.1 \%$ & $18.3 \%$
\end{tabular}

If a product is proven harmful to the environment, would you stop buying it?

\begin{tabular}{llll}
\hline No & $12.8 \%$ & $25.2 \%$ & $2.5 \%$ \\
\hline Yes & $87.2 \%$ & $74.8 \%$ & $97.5 \%$ \\
\hline
\end{tabular}


Rodolfo Jorge Patricio Sapiains Arrué, Gabriela Alejandra Azócar de la Cruz, Ana María Ugarte Caviedes y Javier Alberto Romero Hernández. Chileans, climate change and the natural environment: An audience segmentation study

On the products you buy, does information about their environmental impact appear on the label?

\begin{tabular}{llll}
\hline No, and I am not interested & $0.2 \%$ & $2.3 \%$ & $0.0 \%$ \\
\hline I have not noticed / I don't read the labels & $34.3 \%$ & $35.1 \%$ & $12.7 \%$ \\
\hline No, but I would you like it to appear & $29.9 \%$ & $26.5 \%$ & $8.6 \%$ \\
\hline Yes, in some of them & $32.5 \%$ & $36.1 \%$ & $50.4 \%$ \\
\hline Yes, in all of them & $3.1 \%$ & $0.0 \%$ & $28.3 \%$ \\
\hline Have you installed solar panels in your home? & & & \\
\hline I have not installed solar panels & $85.9 \%$ & $92.6 \%$ & $94.4 \%$ \\
\hline I have installed solar panels & $10.4 \%$ & $4.5 \%$ & $5.6 \%$ \\
\hline I don't know what solar panels are & $0.0 \%$ & $0.0 \%$ & $0.0 \%$ \\
\hline Why haven't you installed them? (solar panels) & & & \\
\hline I don't have the money to do it & $66.1 \%$ & $57.6 \%$ & $80.6 \%$ \\
\hline $\begin{array}{l}\text { I live in a place where you can't do it } \\
\text { I don't know how to do it }\end{array}$ & $10.4 \%$ & $11.0 \%$ & $3.6 \%$ \\
\hline I am not interested & $15.4 \%$ & $10.9 \%$ & $11.7 \%$ \\
\hline I do not see usefulness & $5.3 \%$ & $11.1 \%$ & $2.6 \%$ \\
\hline $\begin{array}{l}\text { The investment is not worth it because they are } \\
\text { inefficient }\end{array}$ & $1.4 \%$ & $2.6 \%$ & $0.0 \%$ \\
\hline
\end{tabular}

** significant association (less than 0.001$)$.

Source: Own elaboration based on the National Survey Environmental and Climate Change 2016, Chile. 
Table 5

\section{Results of the second part of the study}

\begin{tabular}{|c|c|c|c|}
\hline & G1: & G2: & G3: \\
\hline \multicolumn{4}{|c|}{$\begin{array}{l}\text { What feelings and /or emotions arise when you hear the concept "climate change"? } \\
\text { (open ended question) }\end{array}$} \\
\hline Preoccupation & $51.9 \%$ & $40.8 \%$ & $69.0 \%$ \\
\hline Fear & $22.0 \%$ & $17.2 \%$ & $32.0 \%$ \\
\hline Sadness & $17.5 \%$ & $11.1 \%$ & $15.6 \%$ \\
\hline Guilt - shame & $5.0 \%$ & $7.5 \%$ & $14.3 \%$ \\
\hline Confusion & $8.1 \%$ & $4.8 \%$ & $3.1 \%$ \\
\hline Anger & $14.2 \%$ & $14.7 \%$ & $2.8 \%$ \\
\hline Frustration & $8.8 \%$ & $9.0 \%$ & $1.4 \%$ \\
\hline Pessimism & $5.4 \%$ & $2.9 \%$ & $1.3 \%$ \\
\hline Helplessness - hopelessness & $5.8 \%$ & $3.0 \%$ & $0.0 \%$ \\
\hline Indifference & $3.1 \%$ & $3.9 \%$ & $0.0 \%$ \\
\hline \multicolumn{4}{|c|}{ What positive consequences could climate change bring? } \\
\hline None & $56.8 \%$ & $58.3 \%$ & $90.9 \%$ \\
\hline Greater protection of the environment & $29.1 \%$ & $16.3 \%$ & $5.8 \%$ \\
\hline $\begin{array}{l}\text { Greater social development / social equity } \\
\text { / less inequality }\end{array}$ & $4.5 \%$ & $3.5 \%$ & $2.9 \%$ \\
\hline Greater national unity & $7.5 \%$ & $18.5 \%$ & $2.0 \%$ \\
\hline Greater economic growth & $6.2 \%$ & $3.7 \%$ & $1.6 \%$ \\
\hline
\end{tabular}

To what extent do you agree with the following statements about climate change ( 1 = Totally disagree to $4=$ Totally agree $)$

\begin{tabular}{llll} 
It will negatively affect the economy & $31.2 \%$ & $26.8 \%$ & $78.5 \%$ \\
It will increase migrations of people & $28.9 \%$ & $30.2 \%$ & $74.4 \%$ \\
$\begin{array}{l}\text { It will make the price of energy more ex- } \\
\text { pensive }\end{array}$ & $41.7 \%$ & $38.7 \%$ & $81.5 \%$ \\
Food prices will rise & $43.5 \%$ & $42.6 \%$ & $82.3 \%$ \\
It will negatively affect people's daily lives & $41.6 \%$ & $45.5 \%$ & $80.3 \%$ \\
It will generate problems in people's health & $45.6 \%$ & $48.9 \%$ & $81.5 \%$ \\
\hline
\end{tabular}

${ }^{* *}$ Significant association (less than 0.001 ).

Source: Own elaboration based on the National Survey Environmental and Climate Change 2016, Chile. 
Rodolfo Jorge Patricio Sapiains Arrué, Gabriela Alejandra Azócar de la Cruz, Ana María Ugarte Caviedes y Javier Alberto Romero Hernández. Chileans, climate change and the natural environment: An audience segmentation study

Rodolfo Sapiains Arrué. Ph. D. Psychological Factors for Environmental Management, The University of Queensland. Professor of Psychology Department, Universidad de Chile; Researcher in Center for Climate and Resilience Research (CR2); and Collaborator Researcher in Centro de Investigación GAIA Antártica (CIGA), Universidad de Magallanes, Chile. Research lines: climate change, environmental management, conservation psychology. Recent publications: Sapiains, Rodolfo; Ibarra, Cecilia; Jiménez, Guadalupe; O’ Ryan, Raúl; Blanco, Gustavo; Moraga, Pilar \& Rojas, Maisa (2020), "Exploring the contours of Climate Governance from an interdisciplinary perspective", in Environmental Policy and Governance, doi: https://doi.org/10.1002/eet.1912. Sapiains, Rodolfo; Ugarte, Ana María; Aldunce, Paulina; Marchant, Germant; Romero, Javier Alberto; González, Mauro; Inostroza-Lazo, Valentina (2020), "Local Perceptions of Fires Risk and Policy Implications in the Hills of Valparaíso, Chile", in Sustainability, doi: https://www.mdpi.com/2071-1050/12/10/4298. Azócar, Gabriela; Billi, Marco; Calvo, Rubén; Huneuus, Nicolas; Lagos, Marta; Sapiains, Rodolfo \& Urquiza, Anahí (2020), "Climate Change Perception, Vulnerability and Readiness: Inter-Country Variability and Emerging Patterns in Latin America”, in Journal of Environmental Studies and Sciences, doi: https://link.springer.com/article/10.1007/s13412-02000639-0.

Gabriela Azócar de la Cruz. PhD in Sociology, Universidad Alberto Hurtado. Professor of Department of Social Work, Universidad Alberto Hurtado, Chile. Research lines: socioecological systems, governance, climate change, social crisis. Recent publications: Azócar, Gabriela et al. (2020), "Climate change perception, vulnerability, and readiness: inter-country variability and emerging patterns in Latin America", in Journal of Environmental Studies and Sciences, doi: 10.1007/s13412-020-00639-0. Mascareño, Aldo; Cordero, Rodrigo; Azócar, Gabriela; Billi, Marco; Hernández, Pablo \& Ruz, Gonzalo (2018), "Controversies in social-ecological systems: lessons from a major red tide crisis on Chiloe Island, Chile", in Ecology and Society, doi: 10.5751/es-10300-230415. Azócar, Gabriela (2017), "Managing Social Crises through Public Policies: Mitigation and Reform”, in Economia y Politica, doi: 10.15691/07194714.2017.003. 
Ana María Ugarte Caviedes, Doctor in Latin American Studies, Universidad de Chile. Postdoctoral Researcher in Center for Climate and Resilience Research (CR2), Chile. Research lines: socio-environmental conflicts, social movements, social participation. Recent publications: Sapiains, Rodolfo; Ugarte, Ana María; Aldunce, Paulina; Marchant, Germant; Romero, Javier; González, Mauro \& Inostroza-Lazo, Valentina (2020), "Local Perceptions of Fires Risk and Policy Implications in the Hills of Valparaíso, Chile", in Sustainability, vol. 12, no. 10, doi: 10.3390/su12104298. Sapiains, Rodolfo, Ugarte, Ana María \& Hasbún, Julio (2019), "Percepciones del cambio climático en la Isla de Chiloé: desafíos parala gobernanzalocal”, in Magallania, vol. 47, no. 1, Chile, doi: 10.4067/S0718-22442019000100083. Sapiains, Rodolfo, Ugarte, Ana María \& Aldunce, Paulina (2018), "Los significados de la participación para el cambio climático en Chile", in Revista Ambiente y Desarrollo, vol. 21, no. 41, Colombia: Pontificia Universidad Javeriana de Bogotá.

Javier Alberto Romero Hernández. Sociologyst. Master student in Center for Climate and Resilience Research (CR2), Chile. Research lines: socio-environmental problems, scientific dissemination, environmental education. Recent publications: Sapiains, Rodolfo; Ugarte, Ana María; Aldunce, Paulina; Marchant, Germant; Romero, Javier; González, Mauro \& Inostroza-Lazo, Valentina (2020), "Local Perceptions of Fires Risk and Policy Implications in the Hills of Valparaíso, Chile", in Sustainability, vol. 12, no. 10, doi: 10.3390/su12104298. Sapiains, Rodolfo; Aldunce, Paulina; Ugarte, Ana María; Marchant, Germant; Inostroza, Valentina \& Romero, Javier (2019), Informe de Devolución "Trabajando Juntos por Placeres Alto: Prevención comunitaria de incendios forestales”, Santiago, Chile: Centro de Ciencia del Clima y la Resiliencia (CR)2. 